\title{
S. de Gruchy
}

\section{REVERSING THE BIBLICAL TIDE: WHAT KURUMAN TEACHES LONDON ABOUT MISSION IN A POST-COLONIAL ERA ${ }^{1}$}

\begin{abstract}
Through a case study focusing on the shift from the London Missionary Society (LMS) to the Council for World Mission (CWM) this essay argues that there is a hermeneutical circle between the Bible and mission. A particular reading of the Bible led the missionaries of the LMS to Africa, and their concern to promote the Bible led to the translation and printing of the Bible in indigenous languages - most famously into Setswana by Robert Moffat at Kuruman. Inevitably, the availability of the Bible in indigenous languages led to new ways of understanding the church and mission from the perspective of the South. This post-colonial dynamic led to changes in the LMS and to the emergence of CWM in 1977. The essay then pursues the argument by showing how over the thirty years of CWM's life there continues to be the development of a biblical vision for mission that takes seriously the perspectives of the post-colonial world.
\end{abstract}

\section{INTRODUCTION}

In 2007 we celebrated the $150^{\text {th }}$ anniversary of the completion of the Setswana Bible at Kuruman, as well as the $30^{\text {th }}$ anniversary of the Council for World Mission (CWM), the successor to the London Missionary Society (LMS). This essay argues that these two events are connected via the hermeneutical circulation between the Bible and mission, a connection which provides a window into the shift of the centre of Christian gravity from the North to the South. The point is simply this: the translation and printing of the Bible in places like Kuruman began an irreversible process in which the tide of mission has turned back from the South to the North.

1 The research for this paper was undertaken whilst I was Scholar in Residence at the CWM offices in London, August-December 2007. The support and assistance of the Council and the staff in London is humbly acknowledged.

Prof .S. de Gruchy, School of Religion and Theology, University of KwaZulu-Natal, Private Bag X01, Scottsville 3209. E-mail: degruchys@ukzn.ac.za. 
Whereas the LMS was a British-based "sending" agency, in which all the financial and decision-making power was held by Europeans, its successor, CWM, is a global community of 31 churches with decision-making power, personnel and finances shared equally amongst them all, including missionaries being sent from the South to the North (CWM 2008). Symbolically, today Rev. Dr. Des van der Water, a South African and heir of the work of LMS at Kuruman, now sits in London as General Secretary of the CWM, the successor body of the LMS.

To celebrate the printing of the Setswana Bible at Kuruman is therefore to celebrate one of the key moments in this countervailing movement in Christian mission. In doing so we acknowledge the profound point being made by Lamin Sanneh (1989:4):

\begin{abstract}
In its African manifestation, Christianity repeated the tensions of its Judaic and Hellenic phases, namely, a resolve on the part of African Christians to question, and sometimes to renounce, the Western presuppositions of the church. 'Tension' rather than 'schism' describes better what was involved, for the instrument that enabled local criticism to take root and flourish was the translation machinery that mission had itself put in place. We may see this tension in acts of local commitment to the new religion in spite of overt reaction, but, equally important, we may also find this tension working at the level of indigenous participation in Christianity where local converts engage in mutual criticisms or in competition and debate what is appropriately indigenous and authentic. The flowering of Christian activity in modern Africa has taken place in ground suitably worked by vernacular translation.
\end{abstract}

\title{
2. LONDON TO KURUMAN AND BACK TO LONDON
}

To get to the heart of the argument, it will be helpful to first summarise the historical process before substantiating it with a detailed argument so as to prepare the reader for the rest of the essay. A particular reading of the missionary 'mandate' in the Bible drove the representatives of the LMS from London to many parts of the world, including Robert Moffat to Kuruman (De Gruchy 1999). That missionary imperative laid an evangelical emphasis on the need to read the Bible, and so through great effort the Bible was translated, printed and made available in the many indigenous languages of the new converts. Kuruman was the first place in which this was done by the LMS in the South (Butler 1999), and so it both presages and represents this movement. The availability of the Bible in the languages of the South (through many other Protestant missionary agencies as well), lead to new ways of reading the Bible and of understanding mission. This shaped the wider social and political pressures to end the hegemony of colonial Christianity throughout the 
world, climaxing in the Bangkok meeting of the World Council of Churches' Commission for World Mission and Evangelism (CWME) in 1972/3.

These wider pressures, set in motion by the translation of the Bible by the LMS, led to fundamental changes to the LMS itself, through which it became the CWM in 1973. Then in 1977 it began a long process of shifting leadership, decision-making and the sharing of finance and personnel from the North to the South. There was a recognition that mission was "from everywhere to everywhere" (CWM 1975). In a very significant way then, 200 years of missionary work, centred on making the Bible available in indigenous languages, has seen a reverse of missionary direction. This bears out Andrew Walls' (1996:29) point:

New translations, by taking the word about Christ into a new area, applying it to new situations, have the potential actually to reshape and expand the Christian faith.

The Kurumans of the world are now teaching London about mission. The periphery speaks to the centre, reminding us that the Gospel which Moffat made available to the Batswana in their mother tongue has a certain logic that resists domestication. Translating and printing the Bible at Kuruman was a dangerous thing for the churches of the North to do!

Laying out the process as simply as this belies the fact that such hermeneutical circulation has not all been smooth and uncontested. Indeed, as we shall see, CWM has itself taken time to make sense of this. Such a re-discovery of what the Bible has to say about mission has been and remains an ongoing journey of discovery. Much of this is tied up within the internal growth of CWM itself, so it will be important to provide a very brief overview of these developments before turning to the way the Bible has been re-read in the context of world mission.

\section{FROM LMS TO CWM}

The LMS was founded in 1795 in a coffee shop in London, the same year in which Robert Moffat was born (see Lovett 1899). It was a classic "sending" agency that took the Gospel and its benefits from the centre of the British Empire and spread them abroad through the work of missionaries and other agents. As a child of the Eighteenth Century Evangelical Revival, it understood mission to be a Biblical mandate, one that was in direct response to Matthew 28:18-20 (see McKelvey 1999).

The LMS was intentionally an inter-denominational agency but in 1889 (just 5 years after Moffat's death), as other denominations established their own denominational missionary organisations, it was formally recognised as an agency of the British and Irish Congregational churches. In 1966 it became 
known as the Congregational Council for World Mission, and in 1973 following the union of Congregational and Presbyterian Churches in England to become the United Reformed Church, it lost its reference to the Congregational Church and became the CWM (Goodall 1954; Thorogood 1994).

At the same time that this was happening, there was significant movement within thinking about world mission. At the end of 1972 there was a paradigmshifting meeting of the World Council of Churches' CWME in Bangkok with the theme, Salvation Today. This meeting focused on issues such as contextual theology, cultural identity, and relationships between churches of the North and South (WCC 1973). There was growing pressure for the 'mission' churches of the South to be recognised as churches in their own right, and to be set free from the patronising tutelage of the "sending" churches of the North. David Bosch (1991:451) notes:

By the late 1960s it became evident that a decisive shift had taken place
even in the mind of Westerners, from a Europe-centred world to a human-
kind-centred world. Henceforth the churches of the West would increas-
ingly take cognizance of the views of and developments in the younger
churches. Yet even at the Second Vatican Council the voices of Third
World church leaders were still muffled, as they were in Protestant ecu-
menical gatherings of the time. Only since the Catholic Synods of Bishops
and, in Protestantism, since the Bangkok CWME meeting (1973) has it
become clear that global ecclesiastical leadership is inexorably passing
towards Third World Christians.

In the light of the consensus of Bangkok, CWM invited leaders from the churches established through the work of the LMS to attend a meeting in Singapore at the end of 1975 . This was a watershed meeting which proposed far reaching changes to the Council, changes which moved the leadership and management of the society from the British churches to a council of all the churches, including the previous 'daughter' churches. In essence, we can recognise in retrospect that this involved moving the organisation from a colonial missionary society (the LMS) to a post-colonial one (CWM). This was formally initiated in 1977, although the full implications of this needed to be worked out over the ensuing thirty years.

One of the ways this has been done has been through an ongoing reflection on the biblical basis for mission. Indeed, within its short thirty year history, we will note some intriguing shifts in missiological vision. Here we have a window into the on-going hermeneutical dynamic that links the Bible to mission, and see how the tide has begun to be reversed. Not only does the Bible push the church into mission; but the outcome of missionary praxis gives rise to new ways of reading the Bible. London leads to Kuruman; but - through the translation and printing of the Bible - Kuruman speaks back to London. 


\title{
4. A SHIFTING BIBLICAL VISION FOR MISSION
}

As noted above, the key missionary text that shaped the early formation of the LMS was Matthew 28:18-20, the Great Commission. But a further biblical text also characterised the missionary fervour of that period, and provided a justification for mission work amongst the 'heathen'. Bosch (1991:290) points out that

\begin{abstract}
with some justification one could say that the missionary text of the period was Acts 16:9, Paul's vision of the Macedonian man who beseeched him and aid, 'come over ... and help us'. ... By the nineteenth century, as Enklaar has demonstrated in a fine study of the subject, the man from Macedonia became the archetype of non-Christians imploring Christ's messengers to come to their aid.
\end{abstract}

These remained the central biblical justifications for mission throughout the next 150 years - the great commission and the "patronizing charity" of the North (Bosch). But the shift to a post-colonial missionary situation, captured by the move from the LMS to CWM, began to shape a new biblical missiology. ${ }^{2}$ We can watch this unfold as we examine five key documents that outline the shifting missionary theology of CWM through its thirty year existence.

\subsection{Sharing in One World Mission (1975)}

This is the document that shaped the new structures of the CWM. Much of the document is taken up with historical and operational concerns, but the second section concerns the "Theological Setting". Here there is reference to the influence of the ecumenical movement and the work of the World Council of Churches, as well as the Lausanne Covenant. Intriguingly there is only one biblical reference in the entire document, (and even this is for a minor issue); and the heart of the theology is not a biblical text but a confessional statement: "There is a central belief which is our guide and our hope. It is that Jesus Christ lives for all mankind" (CWM 1975: para 2.3). The document takes a very broad approach to mission as can be seen from this defining statement:

There are many words and phrases which are used to express the na-

ture and purpose of Christian mission. For example:

Conversion - forgiveness - new life - eternal hope

Reconciliation - peace - community

2 For the most complete overview of the kinds of dynamics that shaped the move from LMS to CWM see Thorogood 1994. The very fact the two earlier histories of the LMS were each written by a single British person, whereas this text is an edited volume with contributions from people from the indigenous churches (by and large), suggests something of the changes that were taking place in the LMS family. 
Liberation - justice - humanisation

Sacrificial caring - healing - wholeness

Preaching and teaching - baptism — church growth.

It is our belief that all these aspects of Christian mission are true to the New Testament and that none of them can be isolated from the others and made the one controlling emphasis for all missionary work (CWM 1975: para 2.2).

It is worth remembering that this document was not written as a theological text, but is mainly concerned with the organisational changes that were needed within CWM. Nevertheless, the text is foundational for the Council, and certainly helps to set the missiological approach. It is clear that there is the beginning of a shift from the dominance of the "Great Commission" of Matthew 28.

\subsection{The Handbook of the Council for World Mission (1984)}

In taking forward the vision of CWM, a handbook was created to introduce the key elements of the new approach to mission. In this document a key section lays out the theological basis for the work of the Council and draws quite liberally from the 1977 document. However, there are some significant departures which suggest that a deeper theology of mission was being requested. We now read that "the source of CWM's understanding of mission is contained in the Bible", and a new paragraph is added with references to and a brief sentence about four key biblical passages (CWM 1984: para 3.2).

Acts 1:8: But you will receive power when the Holy Spirit has come upon you; and you will be my witnesses in Jerusalem, in all Judea and Samaria, and to the ends of the earth."

John 20:21,22: Jesus said to them again, "Peace be with you. As the Father has sent me, so I send you." When he had said this, he breathed on them and said to them, "Receive the Holy Spirit."

2 Cor 5:18,19: All this is from God, who reconciled us to himself through Christ, and has given us the ministry of reconciliation; that is, in Christ God was reconciling the world to himself, not counting their trespasses against them, and entrusting the message of reconciliation to us.

John 17:21: "... that they may all be one. As you, Father, are in me and I am in you, may they also be in us, so that the world may believe that you have sent me."

As with Sharing in One World Mission there is no reference to Matthew 28:19, the 'Great Commission'. The debt to the ecumenical movement continues to be strongly noted, with a long quotation from the WCC's document, 
"Mission and Evangelism — an Ecumenical Affirmation" of July 1983. And then a strong theological statement is made:

The expressed object of the Council for World Mission is "to spread the knowledge of Christ throughout the world". CWM seeks to achieve this object by its member Churches assisting one another in:

- Preaching the gospel and proclaiming the good news of Christ to all people in all places and in all situations where God's love in Christ is not known.

- Incarnating the love of Christ to those who are in need

- Demonstrating his love to the poor

- Making his love real to those who are suffering any injustice - racial, economic, social or political

- Working for reconciliation within all communities

- Making the Gospel credible by working toward the unity of the Church.

This means bringing healing, wholeness, liberation and a sense of dignity and worth to every human being. Jesus who came proclaiming the kingdom of God has made plain that God's purpose embraces all humankind and all creation. God our creator is Lord of all. Those who are in Christ are new creatures and one day God will bring to completion his creation of a new heaven and a new earth (CWM 1984: para 3.3).

Whilst the early LMS missionaries were not averse to engaging in social and political matters of the day, as our own Theodorus van der Kemp and John Philip illustrate, it is doubtful that they (or other LMS missionaries in Southern Africa like Moffat and John Brownlee) would have understood mission in quite these terms. In other words we are witness to a wider biblical understanding of mission that is emerging through the reading and reflection of people of the South.

\subsection{The CWM Handbook (1991)}

The Handbook was revised in 1991, and the "theological statement" was changed once again. This was because "the Churches, partnership in mission relationships, have grown and new theological and missiological insights have developed". In this document the four biblical texts noted above became the framework for an extensive theology of mission, one that seeks to integrate some of the concerns of both Sharing in One World Mission and the 1984 Handbook. Acts 1:8 is taken as "the basis of mission". This text leads to a discussion of the missio Dei, the work of the Spirit, and problems with the idea of "foreign missions". 
Acts $1: 8$ calls us to a singular purpose of discerning the presence of the Spirit ahead of us in mission and of being present with God anywhere, everywhere, wherever one is or wherever one is sent (CWM 1991:6).

John 20:21 signals the 'Pattern of our Mission', for it is the call "to do Mission in Christ's way", most importantly through working with the disadvantaged.

II Corinthians 5:18, which speaks of the work of reconciliation, provides "the goal of mission". It is noted that:

\begin{abstract}
reconciliation is not possible without justice. Therefore, prophetic critique of unjust structures, solidarity and pain-bearing with the oppressed, envisioning the new possibilities in Christ and empowering people in their struggle are essential elements of the mission of the Church today (CWM 1991:8).
\end{abstract}

Finally John 17:21 helps us see "Mission and unity as inseparable correlates". "The very way in which communities of Churches like CWM are involved in partnership is to demonstrate, as first fruits, God's ultimate purpose for the unity of humanity" (CWM 1991:8).

\title{
4.4 Perceiving frontiers, crossing boundaries (1995)
}

Four years after the 1991 Handbook, CWM hosted a 'Partnership in Mission Consultation' at High Leigh, UK. This was an occasion to reflect on the past two hundred years of mission (given that it was the bicentenary of the founding of the LMS), and to chart the way forward in response to the 'gift of grace'. A report was adopted, Perceiving frontiers, crossing boundaries, which affirms much of what we have noted about CWM's mission theology, but which also suggests new themes. There is a re-statement of CWM's holistic understanding and practice of mission, drawn from the ministry and mission of Jesus himself. This is followed by a reaffirmation of the four biblical texts that we have noted above, with the comment that:

these texts were not simply collected at random, but came out of the mission practice of CWM that uses the action-reflection model of discerning the mission of the church in terms of God's mission (CWM 1995: para 19).

Three new themes and texts are then introduced, reflecting once again the changed social circumstances of the world. The end of the Cold War has now led to the impact of neo-liberal economic globalisation, and threats to the environment, justice and the diversity of cultures. As would be expected from an organisation that is keen to engage the Bible with the context, we see these new concerns reflected in the document. First is the whole area of 'creation', possibly suggested by the fact that the then General Secretary of CWM, D. 
Preman Niles, was deeply involved in the World Council of Churches work on Justice, Peace and the Integrity of Creation. The text that is engaged here is Psalm 24:1. The second theme is "the Reign of God as an alternative dimension of hope for resisting the threats to life" (CWM 1995: para 20), and this is rooted in Jesus' Nazareth Manifesto (Luke 4:18-19), and the Beatitudes in Matthew 5:3-10 (CWM 1995: para 21).

For the third theme, to do with nations and cultures, the document surprisingly turns back to the Great Commission in Matthew 28:18-20, a text that we have noted has been conspicuous by its absence in CWM mission thinking. Of importance is the idea of 'the nations' which are to be baptised and taught. This provides an opportunity to reflect upon the nation as an inclusive entity that should be non-fragmented, thus showing respect for, "their identifiable religious cultures with which they have been endowed by God" (CWM 1995: para 22).

\subsection{World Mission Today (1999)}

The document, Perceiving frontiers, crossing boundaries was shared with the member churches of CWM, and then a working group of twelve people under the leadership of Niles was brought together in 1998 to reflect on the comments and to revise the document. However, after due consideration it was decided to produce a new document, World Mission Today, which is the most comprehensive and all embracing missiological statement coming from CWM. This document, which was adopted by CWM in 1999, begins with a review of the previous statements that we have identified above - and which are acknowledged and accepted - and then lays out new themes and challenges for mission. In doing so it presents quite a different approach to missiological thinking, by beginning not with New Testament texts about mission (contra all the earlier documents, including those guiding the LMS), but by beginning with the Old Testament.

By so gaining an understanding of God's work in the world, the missio Dei, the document roots mission in the doctrine of God, rather than the work of Christ or the Spirit. The feeling is that such an approach enables a theology of mission to deal with the same three pressing contextual issues noted above, namely, globalisation, the ecological crisis, and genuine respect for people of other faiths (CWM 1999: para 2.1):

To address the implications and challenges of such a complex situation, we need an adequate theological framework for mission. To do this we turn to the biblical witness of the missionary God who reaches out in creation and redemption (CWM 1999: para 2.2).

In doing this there is a great deal of engagement with the first four chapters of Genesis, which provides the basis of thinking about creation, community, 
and partnership (CWM 1999: paras 2.3-2.6). There is a strong critique of reading the Bible as the exclusive text of a particular people, and an engagement with those texts that speak of God's universalism (Amos 9:7; Isaiah 19:19-24; Jonah, and Ruth):

Since the principle of partnership is at the heart of existence, it follows that we cannot achieve fullness without partnership with all people and with all of creation. Together, the presence of the Spirit in all of creation and the image of God in all of humanity point to the universality of God's presence and activity. God is not limited to one part of creation or to one part of humanity (CWM 1999: para 2.9).

Following this the document takes a Christological turn by seeing the incarnation of God in Christ as the full proclamation and pattern of God's work, and this parallels earlier statements by CWM. However, a further new development is an eschatological vision which points to "people from every nation, tribe and language coming before God with their own gifts, their own voices and their own cultures (Rev 7:9; 21:22-27)" (CWM 1999: para 2.14).

The document then turns to read the 'signs of the times' (Section 3), and then returns in section 4 to "Our Missionary Calling: Partners in God's Mission". This identifies four areas in which we are called to be partners in God's mission: (i) in being a sign of hope; (ii) in having a holistic understanding of mission; (iii) in having Christ's way as the model for our mission; and (iv) in forming wider partnerships for mission. Much of this is a restatement of the themes that have characterised the missionary vision of CWM since 1977, although there is a greater openness to issues of creation and inter-religious dialogue.

\section{THE BIBLE IN MISSION AND MISSION IN THE BIBLE}

This historical overview of the changing way in which one missionary organisation has sought to understand mission bears testimony to the claim of this paper, namely, that not only does the Bible shape the way people engage in mission, but that every missionary engagement shapes the way people read the Bible. London leads to Kuruman. But the Kurumans of the world speak back to London. Drawing together the historical threads we can note the following about this hermeneutic within the life of CWM. 


\subsection{An open creative space for rethinking mission and the Bible}

The original vision of the LMS was not only geographically unidirectional, it was also theologically unidirectional. The Churches in the North acted on the assumption that they knew what was needed, and that they understood the missionary mandate. They went to Kuruman in obedience to this. The growing multidirectional movement in world mission which gave birth to CWM, has also given birth to a far less top-down theology of mission. Our survey of the changes in CWM's biblical understanding of mission suggests that there is no "final" received mission theology in the organisation, but that it has rather created space for rethinking mission and the Bible.

We see this in the way in which certain biblical texts emerge, and then become important. (Acts 1:8; John 20:21, 22; 2 Cor 5:18,19; and John 17:21). Then they in turn are relegated to a lower place as the Council grapples to deal with the realities of environmental crises, globalisation and religious pluralism. By the end of our survey we see a greater reliance on the Old Testament, grounding mission not in Christology or Pneumatology, but in the doctrine of God and the missio Dei.

\subsection{The ongoing importance of the Bible}

The LMS was part of the Evangelical Revival in Britain, and it took the Bible and reading the Bible very seriously. This is why such a huge effort and so many resources were put into literacy, translation and printing (De Gruchy 1999). For Moffat and others rooted in the Evangelical tradition, one simply could not be a Christian if one did not read the Bible. What our survey shows is that the Bible continues to be central to the work of CWM. We noted that in the first document in 1977, there is almost no biblical vision at all. It is as if the assumed Biblical vision for the LMS would continue into the new CWM. This was rooted in the Great Commission of Matthew 28:18-20, but with a broad ecumenical vision of mission shaped by the work of the World Council of Churches.

However, by 1984 we see the statement that "the source of CWM's understanding of mission is contained in the Bible," and the 1991 document grounds the basis, pattern and goal of mission on three biblical texts (Acts 1:8; John 20:21,22; and 2 Cor 5:18,19). The engagement with the key social themes of globalisation, environmental degradation and religious pluralism is also rooted in a biblical response. Finally, the shift to the Old Testament is a strong pointer to the fact that CWM seeks to engage not just with one or two texts in the Bible, but with the wider witness of the whole Bible. 


\subsection{Mission as the work of God}

The key missionary insight of twentieth century Protestantism was the recovery of the idea of the missio Dei (see Bosch 1991). This reminds us that God is a missionary God who invites the church to participate in his work. In this scheme, mission is primary, and the church finds its raison d'être in its willingness to respond to and engage in God's mission. As we track the developing missionary theology of CWM through the past thirty years, we see a growing realisation of the importance of this. The pressures of globalisation, environmental degradation and religious pluralism call for a missiological perspective that is broader than just a few New Testament texts that prioritise evangelism.

We see this beginning in 1995 when the document Perceiving frontiers, crossing boundaries engages with Psalm 24:1, Luke 4:18,19, Matt 5 and reworks the traditional text of Matt 28:18-20. This movement comes to greater maturity in the 1999 document, World Mission Today, with a theology that begins with God the Father, rather than Christ or the Spirit. This is felt to provide a stronger foundation in terms of the environment, globalisation and pluralism. With this shift comes a far greater reliance on the OT, and Genesis is seen to be the starting point for a theology of mission. Attention is also given to those texts that speak of God's universalism (Amos 9:7; Isaiah 19:19-24; Jonah and Ruth). There is also a new eschatological element with an emphasis on "the nations" (Rev 7:9; 21:22-27).

\subsection{From everywhere to everywhere}

One of the early ways of capturing the shift from the "sending" agency of the LMS to the "partnership" agency of CWM was the use of the phrase, "from everywhere to everywhere". This promoted the idea that mission was not primarily the work of sending the gospel from London to Africa, Asia, the Caribbean or the Pacific, but that all Christians were called to be engaged in mission in their own context. This also implied a reversal that would involve the taking of the gospel from the South back to the North. While it took a long time for this to become a reality, by 2000 CWM supported more missionaries from the South than from the North. The vision of a global post-colonial missionary movement and partnership is now a reality.

\section{CONCLUSION}

What we recognise then is that by translating and printing the Bible at Kuruman (and elsewhere), the LMS participated in a movement that ultimately led to its demise as a colonial mission society. For the Bible carries a liberating message of human dignity and creativity in response to God's grace. Thus we 
should not be surprised that the printing of the Bible in the South, in places like Kuruman, unleashed similar impulses to those that followed the printing of the Bible in Europe, namely the Protestant Reformation and the Catholic counterReformation. While Sanneh is focusing on the specific dynamics within Africa, he nevertheless gets to the heart of the process:

This situation could not have been avoided by mission as translation. The concession that missionaries made that local populations may legitimately call upon the God of the Bible in their own language turned out to be a major step in bringing forward the indigenous framework as the basis for assimilation. The subsequent attempts to qualify his assimilation by attaching Western cultural conditions were a cosmetic resort. The larger procedure had struck at the heart of any normative claims for Western culture so far as effective mission is concerned (Sanneh 1989:178).

Moffat's work in translating and printing the Bible at Kuruman 150 years ago, can therefore be seen as both the climax of a certain way of understanding mission, and the planting of the seed for a new way of doing so. In this way it signals the start of a reversal of the tide, and can be understood not just as what London contributed to Kuruman, but the genesis of what Kuruman would ultimately contribute to London. Sanneh is right: "The instrument that enabled local criticism to take root and flourish was the translation machinery that mission had itself put in place" (Sanneh 1989:4).

This should remind us that it is not just that the Bible teaches us about mission, but that mission also teaches us to read the Bible. And it is in the ongoing praxis of this hermeneutical circulation of Bible and mission that we learn again that the gospel has a way of empowering Kuruman against London, the periphery against the centre, and the weak against the strong. This is surely the heart of the missio Dei. 


\section{BIBLIOGRAPHY}

$\mathrm{Bosch}, \mathrm{D}$.

1991. Transforming mission: Paradigm shifts in Theology of Mission. Maryknoll: Orbis.

Butler, A.

1999. Kuruman: The work of the LMS in Bechuanaland. In: S. de Gruchy (ed.), Changing frontiers: The missionary story of the UCCSA (Gaborone: Pula Press), pp. 38-47.

\section{CWM}

1975. Sharing in One World Mission. London: CWM.

1984. Handbook of the Council for World Mission. London: CWM.

1991. Council for World Mission Handbook. London: CWM.

1995. Perceiving frontiers, crossing boundaries. London: CWM.

1999. World Mission Today. London: CWM.

2008. CWM [Online] Retrieved from: www.cwmission.org. [2008, 21 July].

De Gruchy, S.

1999. The alleged political conservatism of Robert Moffat. In: J.W. de Gruchy (ed.), The London Missionary Society in Southern Africa: Historical essays in celebration of the bicentenary of the LMS in Southern Africa, 1799-1999 (Cape Town: David Philip), pp. 17-36.

GoOdALL, N.

1954. History of the LMS. London: Oxford University Press.

LOVETT, R.

1899. History of the London Missionary Society, Volumes 1 and 2. London: Oxford University Press.

McKelvey, J.

1999. Mission then and now: Reflections on the founding of the LMS. In: S. de Gruchy (ed.), Changing frontiers: The missionary story of the UCCSA (Gaborone: Pula Press), pp. 199-210.

SANNEH, L.

1989. Translating the message: The missionary impact on culture. Maryknoll: Orbis.

THOROGOOD, B. (ED.)

1994. Gales of change: Responding to a shifting missionary context. The story of the London Missionary Society 1945-1977. Geneva: WCC.

Walls, A.

1996. The missionary movement in Christian history: Studies in the transmission of faith. Maryknoll: Orbis. 


\section{WCC}

1973. World Council of Churches Bangkok Assembly 1973: Minutes and Report of the Assembly of the Commission on World Mission and Evangelism of the World Council of Churches. Geneva: WCC.

Keywords

Mission

Bible

Hermeneutical circle

Post-colonial
Trefwoorde

Sending

Bybel

Hermeneutiese sirkel

Post-koloniaal 